\title{
The Reported Adverse Effects Related to Biological Agents Used for the Treatment of Rheumatic Diseases in Turkey
}

\author{
Romatizmal Hastalıkların Tedavisinde Biyolojik Ajanların Kullanımına Bağlı Türkiye'de \\ Bildirilmiş Yan Etkiler
}

\author{
Erkan KILIÇ, ${ }^{1}$ Gamze KILIÇ,, Özgür AKGÜL, ${ }^{1}$ Gürkan AKGÖL, ${ }^{2}$ Salih ÖZGÖÇMEN ${ }^{1}$ \\ ${ }^{1}$ Department of Physical Medicine and Rehabilitation, Medical Faculty of Erciyes University, Division of Rheumatology, Kayseri, Turkey \\ ${ }^{2}$ Department of Physical Medicine and Rehabilitation, Bingöl State Hospital, Bingöl, Turkey
}

Objectives: This study aims to review the reported adverse events related to the use of biological agents used for the treatment of rheumatic diseases in Turkey.

Patients and methods: Between January 2000 and January 2012, the literature was searched in English and Turkish for case reports and case series using the MedLine, Web of Science, and Scopus databases reporting adverse effects related to the use of biological agents including infliximab, etanercept, adalimumab, anakinra, rituximab which were used for the treatment of rheumatic diseases.

Results: A total of 53 patients (21 males, 32 females) with rheumatic disease who suffered from adverse effects related to the use of biological agents were reported in Turkey in the literature. The mean age was $39.0 \pm 15.6$ years, while the mean disease duration was $10.6 \pm 8.2$ years. The mean time from the initiation of the biological agents to the onset of the adverse events was $8.8 \pm 9.2$ months. The most frequently seen biological agentrelated adverse effects were observed in patients with ankylosing spondylitis (AS) and rheumatoid arthritis (RA). Tuberculosis (TB) was the most commonly reported adverse effect with in 14 patients (26.4\%). Other adverse events included psoriasis (15.1\%), solid tumors (7.6\%), lymphoma (5.7\%), drug-induced lupus (3.8\%), and menstrual bleeding (3.8\%). A total of $77.4 \%$ patients who suffered from adverse events discontinued biological therapies.

Conclusion: Biologic agents are relatively safe; however, they may rarely lead to serious adverse events. As tuberculosis is a moderate endemic disease in Turkey, patients who are scheduled for biological agents (anti-TNF and abatacept particularly) should be informed about the potential risks of biological therapy and monitored closely before and after the initiation of treatment.

Key words: Adalimumab; adverse event; biological agent; etanercept; infliximab; rheumatic disease; rituximab.
Amaç: Bu çalışmada Türkiye'de romatizmal hastalıkların tedavisinde kullanılan biyolojik ajanlara bağlı gelişen bildirilmiş yan etkiler derlendi.

Hastalar ve yöntemler: Ocak 2000 ile Ocak 2012 tarihleri arasında romatizmal hastalıkların tedavisinde kullanılan infliksimab, etanersept, adalimumab, anakinra, rituksimab dahil olmak üzere biyolojik ajanlara bağlı gelişen yan etkileri bildiren olgu ve olgu serileri MedLine, Web of Science ve Scopus veri tabanları kullanılarak İngilizce ve Türkçe dillerinde tarandı.

Bulgular: Literatürde Türkiye'den biyolojik ajana bağlı yan etki görülen romatizmal hastalıklı toplam 53 olgu (21 erkek, 32 kadın) bildirilmiştir. Yaş ortalaması $39.0 \pm 15.6 \mathrm{yıl}$ ve ortalama hastalık süresi $10.6 \pm 8.2 \mathrm{yıl}$ idi. Biyolojik ajanlara başlanması ile yan etkinin ortaya

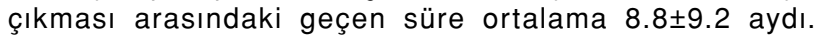
Biyolojik ajan kullanımına bağlı olarak en sık görülen yan etki ankilozan spondilit (AS) ve romatoid artrit (RA) hastalarında gözlendi. En sık bildirilen yan etki 14 hastada (\%26.4) tüberküloz idi. Diğer yan etkiler psöriyazis (\%15.1), solid tümör (\%7.6), lenfoma (\%5.7), ilaca bağlı lupus (\%3.8) ve menstrüel kanama (\%3.8) idi. Yan etki gelişen olguların toplam \%77.4'ünde biyolojik tedaviler sonlandırıldı.

Sonuç: Biyolojik ajanlar nispeten güvenli olmakla beraber, nadiren ciddi yan etkilere neden olabilir. Türkiye'de tüberküloz orta derecede endemik bir hastalık olması nedeniyle, biyolojik ajan tedavisi (özellikle anti-TNF ve abatasept) planlanan hastalar tedavi öncesinde ve tedaviye başladıktan sonra tedavinin olası riskleri açısından bilgilendirilmeli ve yakından takip edilmelidir.

Anahtar sözcükler: Adalimumab; yan etki; biyolojik ajan; etanersept; infliksimab; romatizmal hastalık; rituksimab.

Received: October 12, 2012 Accepted: February 21, 2013

Correspondence: Erkan Kıııç, M.D. Erciyes Üniversitesi Tıp Fakültesi Fiziksel Tıp ve Rehabilitasyon Anabilim Dalı, Romatoloji Bilim Dalı, 38039 Talas, Kayseri, Turkey. Tel: +90 352 - 2076666 / 21276 e-mail: erkan1978@yahoo.com 
In the last two decades, the use of biological agents which target the key molecules in the disease process has become increasingly more important in clinical practice. The current biological therapies for rheumatic diseases include the inhibition of tumor necrosis factor (TNF), interleukin (IL)-1, IL-6, co-stimulation blockade, and B cell depletion. Biologics usually have significant effects since they rapidly decrease the inflammatory process, improve clinical and laboratory signs, and retard the radiographic progression of the disease. These developments have even led to the new term "era of biologics" for the treatment of rheumatic diseases.

The United States Food and Drug Administration (FDA) has currently approved five TNF inhibitors for the treatment of several rheumatic diseases, and in Turkey, patients using etanercept, infliximab, and adalimumab to treat several rheumatic diseases can be reimbursed for these medications. Infliximab, the first marketed anti-TNF in Turkey, is a chimeric monoclonal antibody (mAb) directed against TNF which is administered via intravenous infusion every six or eight weeks. ${ }^{[1]}$ Etanercept is a soluble p75 TNF receptor fusion protein that is subcutaneously administered once or twice a week, and adalimumab is a recombinant human $\mathrm{mAb}$ which is given subcutaneously every other week. ${ }^{[1]}$

Two relatively new options are also available for treatment for rheumatoid arthritis (RA) in Turkey, and reimbursement is also possible. Abatacept is a soluble fusion protein comprised of the cytotoxic $\mathrm{T}$ lymphocyte antigen 4 (CTLA-4) and the Fc portion of immunoglobulin G1 (IgG1) that prevents CD28 from binding to its counter-receptor, CD80/CD86, due to its higher affinity for CD80/CD86. It is administered via intravenous infusion approximately every four weeks. ${ }^{[2]}$ Rituximab is a human/mouse chimeric B cell-depleting monoclonal anti-CD20 antibody that is administered via intravenous infusion every six months. ${ }^{[2]}$ Approval of these drugs is relatively new compared with the anti-TNF drugs which have been on the market for nearly 10 years in our country.

In Turkey, patients can be reimbursed for all of these drugs for the treatment of approved rheumatic diseases if they are prescribed by a rheumatologist or physiatrist working in a tertiary center and indications are in accordance with internationally accepted guidelines or recommendations (but with minor changes on them). In addition, the Ministry of Health has welcomed them for off-label use for special indications such as Behçet's disease (BD), familial Mediterranean fever (FMF), and adult Still's disease. Furthermore, they have also been approved for treating vasculitis if the patient failed to respond to conventional treatments.

The use of anti-TNFs has revolutionized the treatment of rheumatic diseases, even though they may cause various adverse events since TNF- $\alpha$ also has various physiological effects since it is utilized to fight against infectious agents and malignant cells and regulate apoptosis. Thus, a TNF- $\alpha$ blockade may have a tendency to cause infectious diseases, malignancies, and autoantibody production. ${ }^{[3,4]}$ One of the most important infections associated with antiTNF therapy is tuberculosis (TB), as several studies have proven that the risk for this disease increases during treatment with anti-TNF agents. ${ }^{[5-8]}$ Animal studies have also shown that TNF- $\alpha$ plays a key role in the formation and maintenance of granuloma. Additionally, numerous studies have shown that fatal reactivation occurred in animals infected with $\mathrm{TB}$ who received a subsequent blockade of TNF- $\alpha .{ }^{[9]}$ Other frequently reported side effects include respiratory infections and injection site reactions associated with the use of anti-TNF agents. ${ }^{[10,11]}$ Skin lesions, such as cutaneous vasculitis, psoriasis, erythema multiforme (EM), or subcutaneous lupus erythematosus (SLE), have also been frequently reported in patients with RA who are being treated with anti-TNFs. ${ }^{[12-14]}$ Furthermore, serious skin infections, for example folliculitis perforans, cellulitis, and necrotizing fasciitis have also been reported. ${ }^{[12,15-17]}$ Biologics have been used for the treatment of rheumatic diseases for nearly ten years in Turkey, and there have been reported adverse events that have been associated with their use. However, the lack of a reliable, frequently updated, formal data registry poses some difficulty for comparing our data regarding these adverse events with other countries. Thus, the aim of our study was to collect data on reported adverse effects associated with biological agents during the treatment of rheumatic diseases in Turkey.

\section{PATIENTS AND METHODS}

We searched the MedLine, Web of Science, and Scopus databases for relevant case reports published between January 2000 and January 2012 and used "Turkey" plus synonyms and combinations of the following terms: "anti-tnf", "tnf", "biologics", "adalimumab", "etanercept”, “infliximab”, “anakinra”, "rituximab", or "abatacept". In addition we manually scanned 
the references of the reviewed articles for other relevant studies. We also limited our literature search to articles that involved human subjects that were published in either English or Turkish.

Four reviewers screened each title and abstract for relevance, and case reports or case series were manually selected from the papers. The reviewers excluded articles based on an abstract review if the report was a review article or meta-analyses, if the biological agents $\mathrm{w}$ ere not used for a rheumatic disease, or if the article and cases did not report the adverse effects of biological agents. Those that met our criteria were then reviewed, and key elements were noted.

\section{Statistical analysis}

All data was analyzed on a personal computer using SPSS for Windows version 15.0 (SPSS Inc., Chicago, IL, USA), and the mean values, standard deviations, and percentages were calculated.

\section{RESULTS}

A flow chart with the entire selection process is shown in Figure 1. All of the reported adverse effects were related to the anti-TNFs, with none being connected to other biologics. The characteristics of these cases are shown in Tables 1 and 2. We identified 53 patients ( 21 males, 32 females; mean age $39.0 \pm 15.6$ years; range 7-72 years) with rheumatic disease who had adverse effects due to biologics. The mean disease duration was $10.6 \pm 8.2$ years (range 1-40), and the mean elapsed time between the initiation of the biological agents and the onset of adverse events was $8.8 \pm 9.2$ months (range $0-48$ ). There were 23 patients (43.4\%) with ankylosing spondylitis (AS), 19 (35.7\%) with rheumatoid arthritis (RA), four (7.6\%) with spondyloarthropathy (SpA), three (5.7\%) with juvenile idiopathic arthritis (JIA), two (3.8\%) with Behçet's disease (BD), one (1.9\%) with juvenile AS, and one (1.9\%) with seronegative arthritis.

Table 3 summarizes the information of all 53 cases together. The most common adverse event was TB in 14 patients (26.4\%), and five of these were treated with infliximab, two with etanercept, and one with adalimumab. Six others were reported as "treated with TNF inhibitors". Furthermore, 12 (22.6\%) of the 14 had pulmonary TB while two (3.8\%) had extrapulmonary TB. In addition, we discovered that chemoprophylaxis was administered for eight (57.1\%) of the $14 \mathrm{~TB}$ patients.

The second most commonly reported adverse event was psoriasis, which was found in eight patients (15.1\%). Five of these were treated with infliximab, two with etanercept, and one with adalimumab. Solid tumors were reported in four cases $(7.6 \%)$, and all of them were treated with etanercept. In addition, there were three cases of lymphoma (5.7\%). Two were treated with etanercept and one with infliximab.

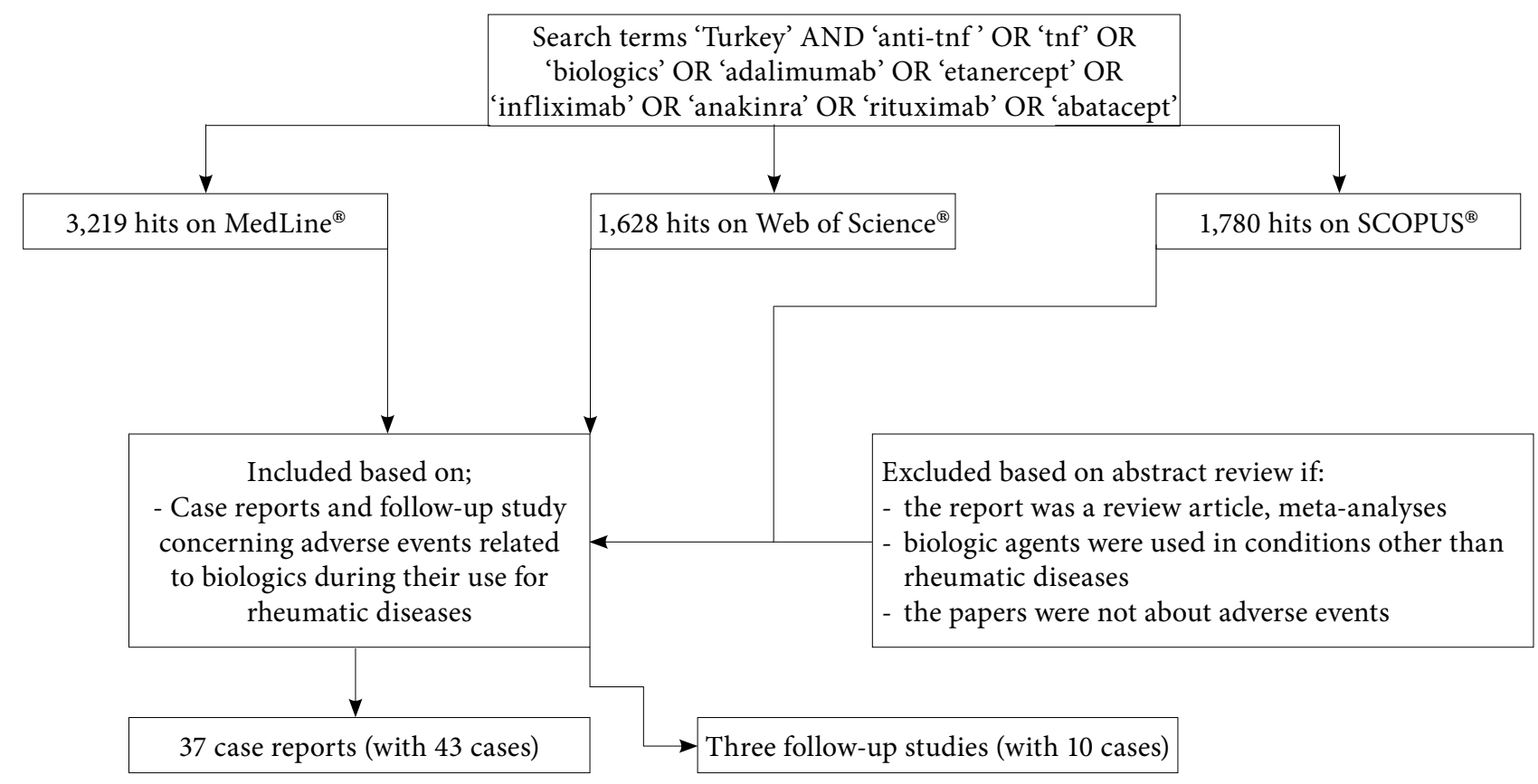

Figure 1. Flow chart. 


\begin{tabular}{|c|c|c|c|c|}
\hline & $\mathrm{n}$ & $\%$ & Mean \pm SD & Range \\
\hline Age (years) & & & $39.0 \pm 15.6$ & $7-72$ \\
\hline \multicolumn{5}{|l|}{ Gender } \\
\hline Male & 21 & 39.6 & & \\
\hline Female & 32 & 60.4 & & \\
\hline \multicolumn{5}{|l|}{ Primary disease } \\
\hline Ankylosing spondylitis & 23 & 43.4 & & \\
\hline Rheumatoid arthritis & 19 & 35.7 & & \\
\hline Juvenile rheumatoid arthritis & 3 & 5.7 & & \\
\hline Unclassified spondyloarthropathy & 2 & 3.8 & & \\
\hline Psoriatic arthritis & 2 & 3.8 & & \\
\hline Behçet's disease & 2 & 3.8 & & \\
\hline Juvenile ankylosing spondylitis & 1 & 1.9 & & \\
\hline Seronegative arthritis & 1 & 1.9 & & \\
\hline Duration of underlying disease (years) & & & $10.6 \pm 8.2$ & $1-40$ \\
\hline \multicolumn{4}{|c|}{ Time elapsed between the start of biologics and } & $0-48$ \\
\hline \multicolumn{5}{|l|}{ Biological therapy } \\
\hline Infliximab & 20 & 37.8 & & \\
\hline Etanercept & 19 & 35.8 & & \\
\hline Adalimumab & 7 & 13.2 & & \\
\hline Anti-TNFs (not specified) & 7 & 13.2 & & \\
\hline \multicolumn{5}{|c|}{ Discontinuation of biologics after adverse events } \\
\hline Yes & 41 & 77.4 & & \\
\hline No & 3 & 5.6 & & \\
\hline Not mentioned & 9 & 17.0 & & \\
\hline \multicolumn{5}{|l|}{ Switch of biologics } \\
\hline No & 48 & 90.6 & & \\
\hline Yes & 5 & 9.4 & & \\
\hline ETA: 2; INF: 1; ADA: 1; RTX: 1 & & & & \\
\hline \multicolumn{5}{|c|}{ INH chemoprophylaxis in patients who developed TB } \\
\hline Yes & 8 & 57.1 & & \\
\hline No & 6 & 42.9 & & \\
\hline
\end{tabular}

Furthermore, there were two cases of drug-induced lupus $(3.8 \%)$, with one having been treated with etanercept and one with infliximab). There were also two cases of serious menstrual bleeding (3.8\%), and adalimumab was used with both patients. In addition, treatment with biological agents was discontinued

Table 2. Characteristics of reported cases by diagnosis

\begin{tabular}{|c|c|c|c|c|c|c|c|c|c|c|c|c|c|c|}
\hline \multirow[t]{2}{*}{$\begin{array}{l}\text { Primary } \\
\text { diagnosis }\end{array}$} & \multirow{2}{*}{$\frac{\text { Patient }}{\mathrm{n}}$} & \multicolumn{2}{|c|}{ Female } & \multirow{2}{*}{$\begin{array}{c}\begin{array}{c}\text { Age } \\
\text { (years) }\end{array} \\
\text { Mean } \pm S D\end{array}$} & \multirow{2}{*}{$\begin{array}{c}\begin{array}{c}\text { Disease } \\
\text { duration (years) }\end{array} \\
\text { Mean } \pm \text { SD }\end{array}$} & \multicolumn{2}{|c|}{ ETN } & \multicolumn{2}{|c|}{ INF } & \multicolumn{2}{|c|}{ ADA } & \multicolumn{2}{|c|}{$\begin{array}{c}\text { Anti-TNF } \\
\text { (not specified) }\end{array}$} & \multirow{2}{*}{$\begin{array}{c}\begin{array}{c}\text { Adverse events } \\
\text { (months) }\end{array} \\
\text { Mean } \pm \text { SD }\end{array}$} \\
\hline & & $\mathrm{n}$ & $\%$ & & & $\mathrm{n}$ & $\%$ & $\mathrm{n}$ & $\%$ & $\mathrm{n}$ & $\%$ & $\mathrm{n}$ & $\%$ & \\
\hline Ankylosing spondylitis & 23 & 11 & 47.8 & $37.70 \pm 9.6$ & $12.8 \pm 8.8$ & 5 & 21.7 & 12 & 52.2 & 4 & 17.4 & 2 & 8.7 & $10.9 \pm 11.6$ \\
\hline Rheumatoid arthritis & 19 & 17 & 89.5 & $49.3 \pm 15.0$ & $10.8 \pm 8.1$ & 10 & 52.6 & 3 & 15.8 & 2 & 10.5 & 4 & 21.1 & $7.7 \pm 6.0$ \\
\hline Juvenile idiopathic arthritis & 3 & 1 & 33.3 & $12.67 \pm 7.6$ & $6.3 \pm 7.6$ & 2 & 66.7 & 1 & 33.3 & - & - & - & - & $6.20 \pm 10.2$ \\
\hline $\begin{array}{l}\text { Spondyloarthropathies other } \\
\text { than PsA and AS }\end{array}$ & 2 & 0 & 0 & $18.50 \pm 3.5$ & $5.0 \pm 2.8$ & 1 & 50 & 1 & 50 & - & - & - & - & $4.10 \pm 4.1$ \\
\hline Psoriatic arthritis & 2 & 1 & 50 & $46.00 \pm 22.6$ & $17.5 \pm 3.5$ & 1 & 50 & 1 & 50 & - & - & - & - & $12.13 \pm 16.8$ \\
\hline Behçet's disease & 2 & 0 & 0 & $25.50 \pm 0.7$ & $2.5 \pm 2.1$ & - & - & 2 & 100 & - & - & - & - & $6.40 \pm 6.5$ \\
\hline Juvenile AS & 1 & 0 & 0 & $20.00 \pm 0.0$ & $5.0 \pm 0.0$ & - & - & 1 & 100 & - & - & - & - & $2.00 \pm 0.0$ \\
\hline Seronegative arthritis & 1 & 1 & 100 & $25.00 \pm 0.0$ & $3.0 \pm 0.0$ & - & - & - & - & - & - & 1 & 100 & $10.00 \pm 0.0$ \\
\hline
\end{tabular}




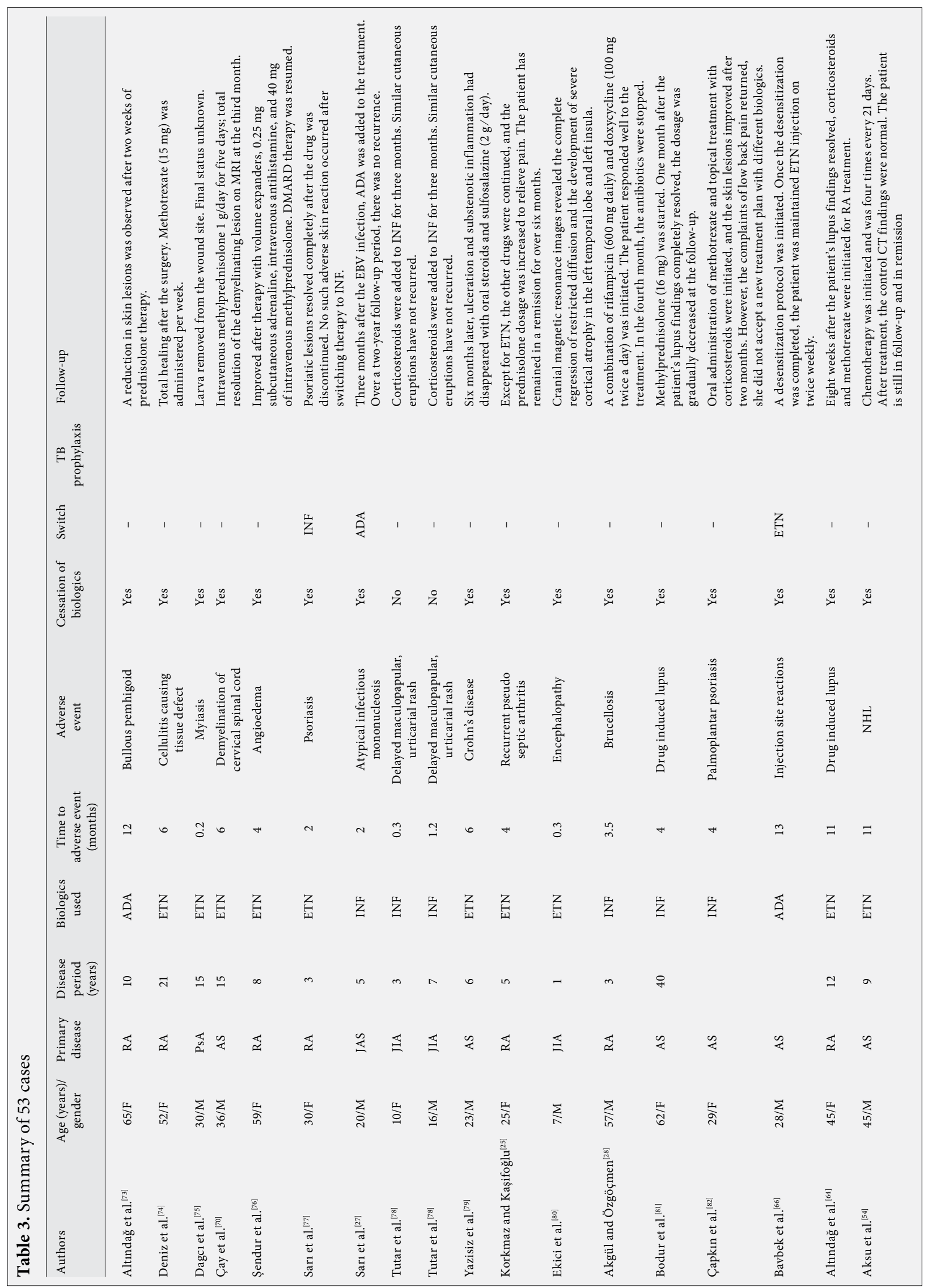




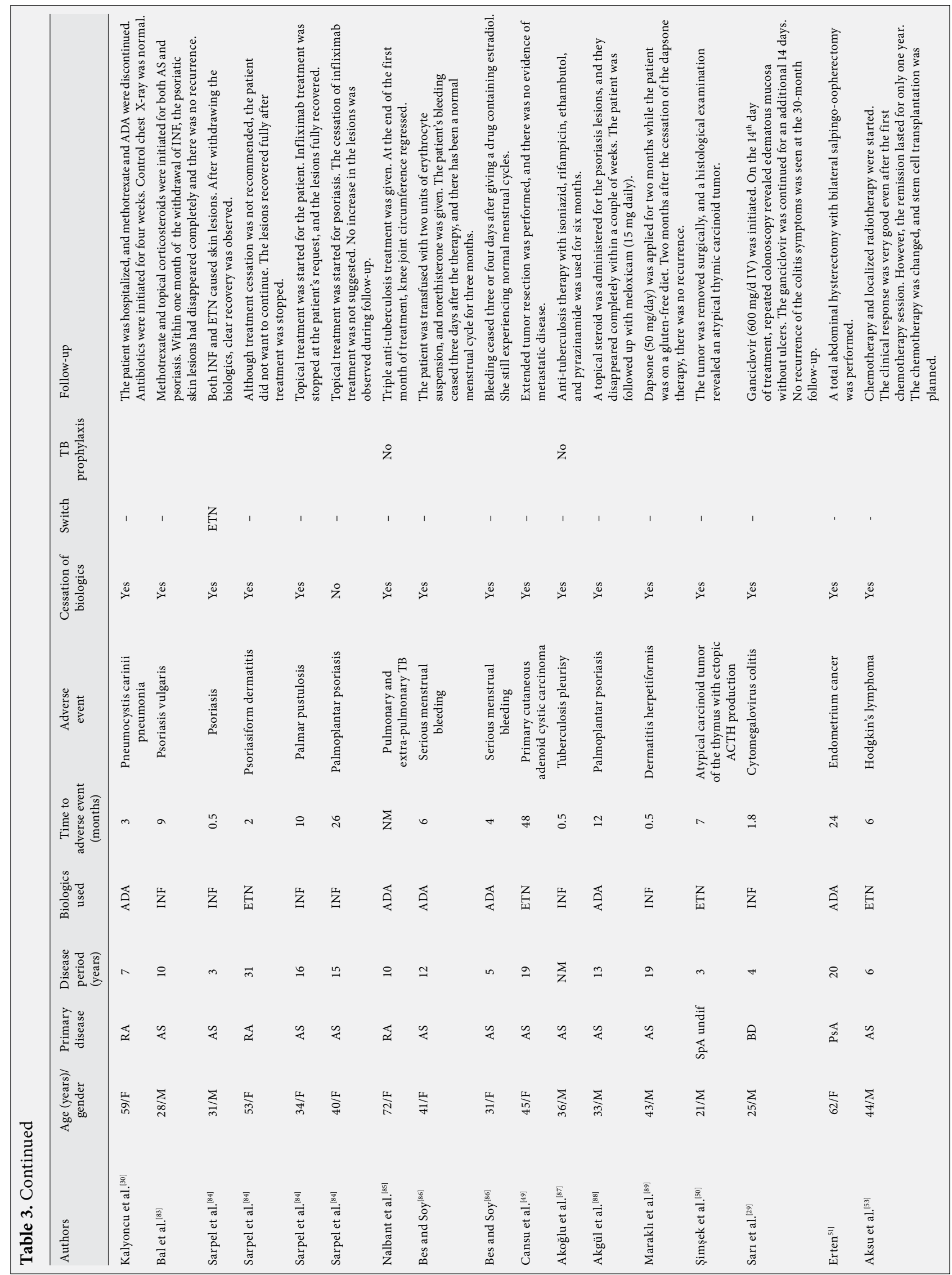




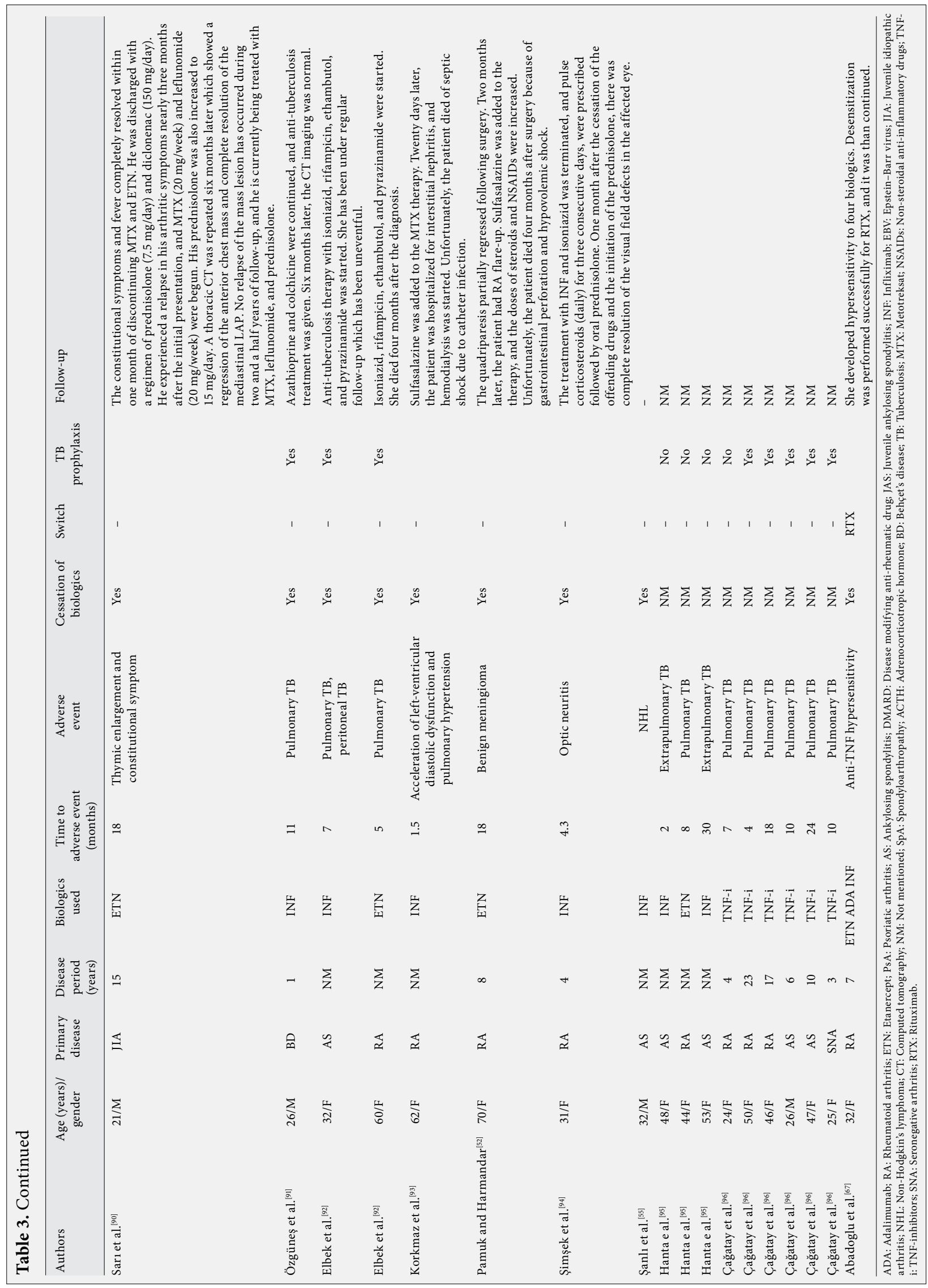


in 41 patients $(77.4 \%)$ and continued in three others (5.6\%), two of whom had a maculopapular rash and one had palmoplantar psoriasis that was treated with infliximab. Data was not available for nine patients (17.0\%), and five (9.5\%) switched to another anti-TNF agent.

Infliximab was used to treat 20 patients $(37.7 \%)$ while etanercept was used for 19 others (35.8\%). Adalimumab was the treatment of choice for seven more (13.2\%). However, which anti-TNF was used has not been specified in seven patients (13.2\%). Patients with RA reported more adverse effects when taking etanercept, whereas AS patients had more problems with infliximab. The elapsed time between the initiation of the biologics and the onset of adverse events was 10.9 \pm 11.6 months for patients with AS and $7.7 \pm 6.0$ months for those with RA.

\section{DISCUSSION}

Herein, we collected data on the reported adverse effects of biological agents used in the treatment of rheumatic diseases in Turkey. Although it could not be generalized, it provided vital knowledge regarding the common adverse events associated with the use biologics in patients of rheumatic diseases.

A Cochrane review showed that patients treated with these drugs developed a significantly higher risk for the total number of adverse events [odds ratio (OR) 1.28], serious infections (OR 1.37), and $\mathrm{TB}$ reactivation (OR 4.68) compared with the control group at standard doses. ${ }^{[18]}$ However, the rates of serious adverse events, lymphoma, and congestive heart failure were not statistically significantly different between the groups. ${ }^{[18]}$

\section{Infections}

A higher rate of upper respiratory infections was observed with anti-TNFs with in clinical trials when compared with placebos. In a study by İnanç and Direskeneli, ${ }^{[19]} 178$ patients with RA [130 took disease modifying antirheumatic drugs (DMARDs); 48 took anti-TNFs] were analyzed for the incidence of infections. The rate of serious infections was 8.6/100 patient years in those treated with DMARDs, but this rate rose to $17 / 100$ patient years during therapy with TNF antagonists. Leombruno et al., ${ }^{[20]}$ reported in a meta-analysis of $8,800 \mathrm{RA}$ subjects treated over an average of 0.8 years that there was no increased risk of serious adverse events when they took the recommended doses of their medication. However, they found that high-dose anti-TNF therapy was associated with a two-fold increase in the risk of serious infections. In addition, the overall infection rate was noted as $13 \%$ in a German biologics registry between 2001 and 2003. ${ }^{[21]}$ This registry also reported that upper respiratory tract infections were seen 32 patients (3.4\%) while TB was seen in only one $(0.1 \%)$. These results suggest that patients treated with antiTNFs have a higher a priori risk of infection. ${ }^{[21]}$ Furthermore, a Spanish biologics registry identified the most common sites of severe infection as being the lower respiratory tract (39\%), the blood (bacteremia/ sepsis) (20\%), and the urinary tract (16\%). ${ }^{[22]}$

The incidence of septic arthritis in the general population varies from $4-10 / 100,000$ patient years. ${ }^{[23]}$ In a British registry, the risk of septic arthritis in 11,881 patients with RA who were treated with antiTNFs was as high as $4.2 / 1,000$, and the authors suggested that the anti-TNF therapy doubled the risk of getting this disease. ${ }^{[2]}$ However, our search yielded only one report related to pseudoseptic arthritis. ${ }^{[25]}$

Opportunistic infections were reported with the use of anti-TNFs, ${ }^{[26]}$ including histoplasmosis, listeriosis, pulmonary aspergillosis, and Pneumocystis (carinii) jiroveci pneumonia. We identified three patients in Turkey with infections related to adverse events who were treated with infliximab and one who was treated with adalimumab. ${ }^{[27-30]}$

\section{Tuberculosis}

Patients treated with anti-TNF therapy have an increased risk for developing $\mathrm{TB}$ and reactivating latent TB because TNF- $\alpha$ is the main cytokine in the immune response against Mycobacterium tuberculosis and granuloma formation. ${ }^{[5,31,32]}$ Moreover, Mycobacterium tuberculosis is the most common granulomatous infection after the use of TNF antagonists. ${ }^{[26]}$ The incidence of TB varies from 9.3 to $449 / 100,000$ in patients treated with anti-TNFs; however, it can differ according to the country, length of the follow-up period, and type of TNF antagonist used. ${ }^{[33]}$ Disseminated TB was more common with monoclonal antibodies. ${ }^{[33]}$ Additionally, the reactivation of latent TB infection leads to significant morbidity and mortality, especially in immunosuppressed patients. ${ }^{[34]}$

According to a result from a British biologics registry, 40 cases of $\mathrm{TB}$ were reported out of the 10,712 patients with RA through April 2008. The adjusted incidence rate (AIR) ratio compared with 
etanercept-treated patients was 3.1 [95\% confidence interval (CI) 1.0-9.5] for infliximab and 4.2 (95\% CI 1.4-12.4) for adalimumab. ${ }^{[35]}$

In a French biologics registry, 69 cases of TB were identified in the patients treated with antiTNFs, but none of the cases received the correct chemoprophylaxis. The gender- and age-adjusted incidence rate of $\mathrm{TB}$ was $116.7 / 100,000$ patient years. Compared with the general population, the standardized incidence ratio (SIR) of TB was 12.2 (95\% CI 9.7-15.5), but it was higher for therapy with infliximab a SIR of 18.6 (95\% CI 13.4-25.8) and adalimumab with a SIR of 29.3 (95\% CI 20.342.4) than for therapy with etanercept with a SIR of 1.8 (95\% CI 0.7-4.3). The authors of this registry concluded that the risk of TB was higher for patients receiving monoclonal antibodies than for those receiving soluble TNF receptor therapy. ${ }^{[36]}$

In a prospective study from the US, the incidence of $\mathrm{TB}$ in RA patients treated with infliximab was $52.5 / 100,000$ patient years, ${ }^{[7]}$ whereas the Ministry of Health of Turkey reported it as 25.8/100,000 between 2007 and 2008. ${ }^{[37]}$

A study from Turkey by Elbek et al. ${ }^{[38]}$ assessed the risk of $\mathrm{TB}$ development in 240 patients with rheumatic disease who were being treated with antiTNF, and they found that the duration of anti-TNF treatment was $17.1 \pm 11.7$ months. Of these 240 patients, only two developed active TB during the follow-up period (13.6 \pm 6.5 months). The incidence of TB in this cohort was estimated at $833 / 100,000$. Based on these results, the authors suggested that anti-TNF therapy increased the risk of TB, despite treatment for latent infections. The rate of latent $\mathrm{TB}$ in this study was 77.6\%. The British Thoracic Society (BTS) suggested that six months of isoniazid treatment is effective and can reduce the risk of developing TB by $60 \% .{ }^{[39]}$ In our study, 14 patients had TB, although eight received isoniazid chemoprophylaxis.

\section{Malignancies}

Because TNF has a tumor-reducing capacity, treatment with anti-TNFs might theoretically promote the formation of tumors ${ }^{[40,41]}$ We found several reports that focused on the risk of lymphoma in patients with RA who were treated with anti-TNF agents.

One Turkish study assessed the association between anti-TNF therapy and the development of tumors among patients in this country with rheumatological diseases. ${ }^{[42]} \mathrm{A}$ total of 2,199 patients
[943 with AS, 931 with RA, 132 with PsA, 127 with juvenile chronic arthritis (JCA), and 66 with other diseases] were collected from 26 different rheumatology centers in Turkey. Fifteen patients had developed malignancies, including 13 with solid cancers and two with lymphoproliferative disorders (SIR: 1.26; 95\% CI 0.70-2.08). The authors stated that the risk of malignancy might differ according to the primary disease (i.e., RA, SpA) and whether an antiTNF agent was used. ${ }^{[42]}$ From 2001 to 2009 , five cases of malignancy (non-Hodgkin's lymphoma, Hodgkin's lymphoma, thyroid carcinoma, yolk sac carcinoma, and cervical dysplasia) were documented in a German juvenile idiopathic arthritis biologics registry which contained 1,260 patients. ${ }^{[2]}$

We found different results regarding the association between malignancies and the use of anti-TNFs. Geborek et al. ${ }^{[43]}$ suggested that the overall incidence of cancer did not increase in patients with RA treated with anti-TNF agents, and that overall, patients with RA have the same increased risk for lymphoma and leukemia. Furthermore, Askling et al. ${ }^{[44]}$ reported that patients with RA who were treated with anti-TNFs did not have a higher risk for lymphoma than those with RA who are treated with DMARDs. In a metaanalysis concerning the safety of biological treatments for RA, no increased risk for lymphoma, melanoma, or non-melanoma skin cancers when patients took the recommended doses was reported. However, the CIs for the risk estimates had quite a wide range. ${ }^{[20]}$

In a large cohort by Chakravarty et al., ${ }^{[45]}$ they found that the use of anti-TNFs and prednisone was associated with an increased risk of non-melanoma skin cancer in patients with RA. Furthermore, a casecontrol study by Baecklund et al. ${ }^{[46]}$ showed that there was a strong association between disease activity and the risk for developing lymphoma in patients with RA.

Mercer et al. $^{[47]}$ in an evaluation of data from a British biologics registry revealed that the SIRs for skin cancer were increased for both anti-TNFs (1.72; 95\% CI 1.43-2.04) and non-biological DMARDs (1.83; 95\% CI 1.30-2.50). In addition, they discovered that the rate of skin cancer increased among patients with RA who were treated with either DMARDs or biologics. The authors underscored that there was no evidence that anti-TNF therapy exacerbated the risk of skin cancer, although this could not be completely excluded. The fact that many cancers develop very slowly and the risk of cancer being associated with the use of biological agents should be further 
examined as experience with these drugs continues to accumulate. ${ }^{[48]}$ In our search of the literature, we found four solid tumors and three lymphomas. ${ }^{[49-55]}$

\section{Skin diseases}

Dermatological adverse events associated with anti-TNF therapy include injection site reactions, allergic rashes, cutaneous infections, psoriasis, drug-induced lupus, erythema multiforme (EM), and cutaneous vasculitis. ${ }^{[56]}$ These are not rare and were reported in $23-25 \%$ of patients with rheumatic diseases who were treated with anti-TNF treatments. ${ }^{[12,57]}$

In a review by Ko et al. ${ }^{[58]} 127$ anti-TNF-related cases of psoriasis were identified. Seventy of these were treated with infliximab (55.1\%), 35 with etanercept (27.6\%), and 22 with adalimumab (17.3\%). The psoriasis was resolved in $64 \%$ of the patients after they stopped using the anti-TNFs and starting systemic therapy. Harrison et al. ${ }^{[59]}$ reported 25 cases of psoriasis in a British biologics registry of 9,826 patients with RA who received anti-TNF- $\alpha$ therapy between January 2001 and July 2007. The authors suggested that the incidence of psoriasis increased in patients who had been treated with anti-TNFs.

Anti-TNF agents can induce lupus-like symptoms. During an eight-year period at the Mayo Clinic, antiTNF-induced lupus was identified in 14 cases. ${ }^{[60]} \mathrm{We}$ also noted that etanercept and infliximab were the two most common causative agents for anti-TNFinduced lupus. ${ }^{[60,61]} \mathrm{Katz}$ and Zandman-Goddard ${ }^{[62]}$ hypothesized that there is always the possibility of latent idiopathic SLE being triggered by antiTNF drugs. Furthermore, in drug-induced lupus, regression of the symptoms is expected if the causative drug is withdrawn. ${ }^{[62]}$ We discovered two reported cases of patients with rheumatic diseases that also had drug-induced lupus in Turkey. ${ }^{[63,64]}$

\section{Others}

Hypersensitivity reactions may occur in patients who are treated with biological agents, but these can be managed by switching to other biological agents or desensitization. ${ }^{[65]}$ In addition, our review found that desensitization was used in a patient with AS who developed an injection site reaction just after using adalimumab and then etanercept. However, after desensitization, the patient could continue to use etanercept without side effects. ${ }^{[66]}$ Desensitization was also achieved in one case with RA who had a hypersensitivity to four different biological agents. ${ }^{[67]}$
Demyelinating disease was associated with the use of anti-TNFs in some patients with underlying neurological symptoms prior to the initiation of the therapy ${ }^{[68]}$ Thus, for patients with preexisting neurological diseases, for example multiple sclerosis (MS), anti-TNF treatment should be avoided, or if such symptoms develop, anti-TNF therapy should be stopped immediately. ${ }^{[68]}$ In a Spanish biologics registry, the incidence rate of demyelinating disease in patients with rheumatic diseases exposed to anti-TNFs was $0.65 / 1,000$ patient years (95\% CI: $0.39-1.1) .^{[69]}$ A patient who had cervical spinal demyelinating disease after etanercept therapy was also reported in Turkey. ${ }^{[70]}$

\section{Safety and efficacy}

We found many papers related to the safety and efficacy of anti-TNF therapies. According to one comparative trial, abatacept and infliximab demonstrated similar efficacy with RA, but abatacept had a relatively more acceptable safety and tolerability profile with fewer adverse events. ${ }^{[71]}$ In addition, discontinuations due to adverse events were lower with abatacept than with infliximab (3.2\% vs. $7.3 \%$, respectively). ${ }^{[1]}$ The data from a British biologics registry revealed that treatment with anti-TNFs was not associated with an increase in mortality when compared with standard DMARD therapies. ${ }^{[72]}$ A regularly updated consensus statement (last updated in 2011) is available in which all of the safety and efficacy data is evaluated by an expert panel. ${ }^{[2]}$

Case reports usually provide weak evidence of causality because they are particularly prone to bias; therefore, the results derived from our review of case reports cannot be generalized. However, it does provide useful information regarding the adverse events related to the use of biologics in Turkey. The results should be carefully evaluated since the vast majority of adverse events probably were not published. In fact, the reported adverse effects were related only to the use of anti-TNFs, but this may be explained by the subsequent approval and inclusion on the reimbursement list of other biologics (i.e., abatacept or rituximab). In fact, the number of reported cases was parallel to the order of approval and reimbursement in Turkey. Infliximab was the first anti-TNF for which patients could be reimbursed for the treatment of RA and AS and was soon followed by etanercept and then adalimumab. Additionally, golimumab has been approved for the 
treatment of RA and AS, but it is not yet reimbursable. Rituximab and abatacept are also newly approved and reimbursable drugs in Turkey for the treatment of RA, but it may be too early to see any reported adverse events related to these drugs in the literature. As expected, the off-label prescription of biologics is also small in this country.

\section{In conclusion}

With the introduction of TNF inhibitors and other biological agents, we have gained effective new treatment options for various rheumatic diseases. Although studies exist which present the safety data related to these biologics, clinicians should be careful and watch for potential adverse events which can be severe. Patients should be informed about this potential risk and monitored closely for any signs of adverse effects associated with their biological treatments. In particular, patients should be screened for TB prior to treatment, especially in countries with a high risk of latent TB like Turkey.

\section{Declaration of conflicting interests}

The authors declared no conflicts of interest with respect to the authorship and/or publication of this article.

\section{Funding}

The authors received no financial support for the research and/or authorship of this article.

\section{REFERENCES}

1. Bachmann F, Nast A, Sterry W, Philipp S. Safety and efficacy of the tumor necrosis factor antagonists.Semin Cutan Med Surg 2010;29:35-47.

2. Furst DE, Keystone EC, Braun J, Breedveld FC, Burmester GR, De Benedetti F, et al. Updated consensus statement on biological agents for the treatment of rheumatic diseases, 2011. Ann Rheum Dis 2012;71 Suppl 2:i2-45.

3. Antoni C, Braun J. Side effects of anti-TNF therapy: current knowledge. Clin Exp Rheumatol 2002;20:S152-7.

4. Cush JJ. Unusual toxicities with TNF inhibition: heart failure and drug-induced lupus. Clin Exp Rheumatol 2004;22:S141-7.

5. Keane J, Gershon S, Wise RP, Mirabile-Levens E, Kasznica J, Schwieterman WD, et al. Tuberculosis associated with infliximab, a tumor necrosis factor alpha-neutralizing agent. N Engl J Med 2001;345:1098-104.

6. Gómez-Reino JJ, Carmona L, Valverde VR, Mola EM, Montero MD; BIOBADASER Group. Treatment of rheumatoid arthritis with tumor necrosis factor inhibitors may predispose to significant increase in tuberculosis risk: a multicenter active-surveillance report. Arthritis Rheum 2003;48:2122-7.
7. Wolfe F, Michaud K, Anderson J, Urbansky K. Tuberculosis infection in patients with rheumatoid arthritis and the effect of infliximab therapy. Arthritis Rheum 2004;50:372-9.

8. Kisich KO, Higgins M, Diamond G, Heifets L. Tumor necrosis factor alpha stimulates killing of Mycobacterium tuberculosis by human neutrophils. Infect Immun 2002;70:4591-9.

9. Kaneko H, Yamada H, Mizuno S, Udagawa T, Kazumi $\mathrm{Y}$, Sekikawa $\mathrm{K}$, et al. Role of tumor necrosis factoralpha in Mycobacterium-induced granuloma formation in tumor necrosis factor-alpha-deficient mice. Lab Invest 1999;79:379-86.

10. Scheinfeld N. A comprehensive review and evaluation of the side effects of the tumor necrosis factor alpha blockers etanercept, infliximab and adalimumab. J Dermatolog Treat 2004;15:280-94.

11. Bathon JM, Martin RW, Fleischmann RM, Tesser JR, Schiff MH, Keystone EC, et al. A comparison of etanercept and methotrexate in patients with early rheumatoid arthritis. N Engl J Med 2000;343:1586-93.

12. Lee HH, Song IH, Friedrich M, Gauliard A, Detert J, Röwert J, et al. Cutaneous side-effects in patients with rheumatic diseases during application of tumour necrosis factor-alpha antagonists. Br J Dermatol 2007;156:486-91.

13. McCain ME, Quinet RJ, Davis WE. Etanercept and infliximab associated with cutaneous vasculitis. Rheumatology (Oxford) 2002;41:116-7.

14. Bleumink GS, ter Borg EJ, Ramselaar CG, Stricker BH. Etanercept-induced subacute cutaneous lupus erythematosus. Rheumatology (Oxford) 2001;40:1317-9.

15. Soliotis F, Glover M, Jawad AS. Severe skin reaction after leflunomide and etanercept in a patient with rheumatoid arthritis. Ann Rheum Dis 2002;61:850-1.

16. Gilaberte Y, Coscojuela C, Vázquez C, Roselló R, Vera J. Perforating folliculitis associated with tumour necrosis factor-alpha inhibitors administered for rheumatoid arthritis. Br J Dermatol 2007;156:368-71.

17. Gerster JC, Dudler J. Cellulitis caused by Capnocytophaga cynodegmi associated with etanercept treatment in a patient with rheumatoid arthritis. Clin Rheumatol 2004;23:570-1.

18. Singh JA, Wells GA, Christensen R, Tanjong Ghogomu E, Maxwell L, Macdonald JK, et al. Adverse effects of biologics: a network meta-analysis and Cochrane overview. Cochrane Database Syst Rev 2011;CD008794.

19. Inanc N, Direskeneli $H$. Serious infections under treatment with TNF-alpha antagonists compared to traditional DMARDs in patients with rheumatoid arthritis. Rheumatol Int 2006;27:67-71.

20. Leombruno JP, Einarson TR, Keystone EC. The safety of anti-tumour necrosis factor treatments in rheumatoid arthritis: meta and exposure-adjusted pooled analyses of serious adverse events. Ann Rheum Dis 2009;68:1136-45.

21. Listing J, Strangfeld A, Kary S, Rau R, von Hinueber $\mathrm{U}$, Stoyanova-Scholz $\mathrm{M}$, et al. Infections in patients with rheumatoid arthritis treated with biologic agents. Arthritis Rheum 2005;52:3403-12. 
22. Díaz-Lagares C, Pérez-Alvarez R, García-Hernández FJ, Ayala-Gutiérrez MM, Callejas JL, Martínez-Berriotxoa A, et al. Rates of, and risk factors for, severe infections in patients with systemic autoimmune diseases receiving biological agents off-label. Arthritis Res Ther 2011;13:R112.

23. Geirsson AJ, Statkevicius S, Víkingsson A. Septic arthritis in Iceland 1990-2002: increasing incidence due to iatrogenic infections. Ann Rheum Dis 2008;67:638-43.

24. Galloway JB, Hyrich KL, Mercer LK, Dixon WG, Ustianowski AP, Helbert M, et al. Risk of septic arthritis in patients with rheumatoid arthritis and the effect of anti-TNF therapy: results from the British Society for Rheumatology Biologics Register. Ann Rheum Dis 2011;70:1810-4.

25. Korkmaz C, Kaşifoğlu T. Development of recurrent pseudoseptic arthritis in a patient with rheumatoid arthritis receiving TNF-alpha blocker. Joint Bone Spine 2006;73:767-8.

26. Keystone EC. Safety of biologic therapies--an update. J Rheumatol Suppl 2005;74:8-12.

27. Sari I, Birlik M, Akar S, Onen F, Kargi A, Akkoc N. Atypical infectious mononucleosis in a patient receiving tumor necrosis factor alpha inhibitory treatment. Rheumatol Int 2009;29:825-6.

28. Akgul O, Ozgocmen S. Infliximab and brucellosis: not the usual suspects, this time. Mod Rheumatol 2011;21:313-5.

29. Sari I, Birlik M, Gonen C, Akar S, Gurel D, Onen F, et al. Cytomegalovirus colitis in a patient with Behcet's disease receiving tumor necrosis factor alpha inhibitory treatment. World J Gastroenterol 2008;14:2912-4.

30. Kalyoncu U, Karadag O, Akdogan A, Kisacik B, Erman M, Erguven S, et al. Pneumocystis carinii pneumonia in a rheumatoid arthritis patient treated with adalimumab. Scand J Infect Dis 2007;39:475-8.

31. Long R, Gardam M. Tumour necrosis factor-alpha inhibitors and the reactivation of latent tuberculosis infection. CMAJ 2003;168:1153-6.

32. Wallis RS, Broder MS, Wong JY, Hanson ME, Beenhouwer DO. Granulomatous infectious diseases associated with tumor necrosis factor antagonists. Clin Infect Dis 2004;38:1261-5.

33. Baronnet L, Barnetche T, Kahn V, Lacoin C, Richez C, Schaeverbeke T. Incidence of tuberculosis in patients with rheumatoid arthritis. A systematic literature review. Joint Bone Spine 2011;78:279-84.

34. Sester U, Junker H, Hodapp T, Schütz A, Thiele B, Meyerhans A, et al. Improved efficiency in detecting cellular immunity towards $M$. tuberculosis in patients receiving immunosuppressive drug therapy. Nephrol Dial Transplant 2006;21:3258-68.

35. Dixon WG, Hyrich KL, Watson KD, Lunt M, Galloway J, Ustianowski A, et al. Drug-specific risk of tuberculosis in patients with rheumatoid arthritis treated with anti-TNF therapy: results from the British Society for Rheumatology Biologics Register (BSRBR). Ann Rheum Dis 2010;69:522-8.
36. Tubach F, Salmon D, Ravaud P, Allanore Y, Goupille P, Bréban $M$, et al. Risk of tuberculosis is higher with antitumor necrosis factor monoclonal antibody therapy than with soluble tumor necrosis factor receptor therapy: The three-year prospective French Research Axed on Tolerance of Biotherapies registry. Arthritis Rheum 2009;60:1884-94.

37. Türkiye'de verem savaşı 2010 raporu. Başak Matbaacılık ve Tan. Hiz. Ltd. Şti, 2010. (Accessed 25.12.12, 2012. Available from: http://www.ehsm.gov.tr/Sub/verem_ savas_dispanseri/files/dokumanlar/turkiyede_verem_ savasi_2010_raporu.pdf.

38. Elbek O, Uyar M, Aydin N, Börekçi S, Bayram N, Bayram $\mathrm{H}$, et al. Increased risk of tuberculosis in patients treated with antitumor necrosis factor alpha. Clin Rheumatol 2009;28:421-6.

39. British Thoracic Society Standards of Care Committee. BTS recommendations for assessing risk and for managing Mycobacterium tuberculosis infection and disease in patients due to start anti-TNF-alpha treatment. Thorax 2005;60:800-5.

40. Williams GM. Antitumor necrosis factor-alpha therapy and potential cancer inhibition. Eur J Cancer Prev 2008;17:169-77.

41. Nair B, Raval G, Mehta P. TNF-alpha inhibitor etanercept and hematologic malignancies: report of a case and review of the literature. Am J Hematol 2007;82:1022-4.

42. Pay S; Society for Research and Education in Rheumatology of Turkey. Risk of cancer in Turkish patients after treatment with TNF antagonists. Rheumatology (Oxford) 2008;47:548-9.

43. Geborek P, Bladström A, Turesson C, Gulfe A, Petersson IF, Saxne T, et al. Tumour necrosis factor blockers do not increase overall tumour risk in patients with rheumatoid arthritis, but may be associated with an increased risk of lymphomas. Ann Rheum Dis 2005;64:699-703.

44. Askling J, Fored CM, Baecklund E, Brandt L, Backlin C, Ekbom A, et al. Haematopoietic malignancies in rheumatoid arthritis: lymphoma risk and characteristics after exposure to tumour necrosis factor antagonists. Ann Rheum Dis 2005;64:1414-20.

45. Chakravarty EF, Michaud K, Wolfe F. Skin cancer, rheumatoid arthritis, and tumor necrosis factor inhibitors. J Rheumatol 2005;32:2130-5.

46. Baecklund E, Ekbom A, Sparén P, Feltelius N, Klareskog L. Disease activity and risk of lymphoma in patients with rheumatoid arthritis: nested case-control study. BMJ 1998;317:180-1.

47. Mercer LK, Green AC, Galloway JB, Davies R, Lunt M, Dixon WG, et al. The influence of anti-TNF therapy upon incidence of keratinocyte skin cancer in patients with rheumatoid arthritis: longitudinal results from the British Society for Rheumatology Biologics Register. Ann Rheum Dis 2012;71:869-74.

48. Solomon DH, Mercer E, Kavanaugh A. Observational studies on the risk of cancer associated with tumor necrosis factor inhibitors in rheumatoid arthritis: a review of their methodologies and results. Arthritis Rheum 2012;64:21-32. 
49. Cansu DU, Kasifoglu T, Açkaln M, Korkmaz C. The development of primary cutaneous adenoid cystic carcinoma in a patient with ankylosing spondylitis treated with etanercept. South Med J 2009;102:738-40.

50. Simsek I, Pay S, Dinc A, Erdem H, Kurt B. Atypical carcinoid tumor of the thymus with ectopic ACTH production developed during the course of etanercept treatment--case report. Clin Rheumatol 2007;26:1561-2.

51. Erten S. Endometrium cancer in a female with psoriatic arthritis treated with TNF alpha antagonist adalimumab. Rheumatol Int 2011;31:1537-8.

52. Pamuk ON, Harmandar F. A case of cervical spine meningioma following etanercept use in a patient with RA. Nat Rev Rheumatol 2009;5:457-60.

53. Aksu K, Donmez A, Ertan Y, Keser G, Inal V, Oder G, et al. Hodgkin's lymphoma following treatment with etanercept in ankylosing spondylitis. Rheumatol Int 2007;28:185-7.

54. Aksu K, Cagirgan S, Ozsan N, Keser G, Sahin F. NonHodgkin's lymphoma following treatment with etanercept in ankylosing spondylitis. Rheumatol Int 2011;31:1645-7.

55. Sanli H, Ataman S, Akay BN, Yilmaz A, Yildizlar D, Gürgey E. Mycosis fungoides in a patient with ankylosing spondylitis during infliximab therapy. J Drugs Dermatol 2007;6:834-6.

56. Kerbleski JF, Gottlieb AB. Dermatological complications and safety of anti-TNF treatments. Gut 2009;58:1033-9.

57. Flendrie M, Vissers WH, Creemers MC, de Jong EM, van de Kerkhof PC, van Riel PL. Dermatological conditions during TNF-alpha-blocking therapy in patients with rheumatoid arthritis: a prospective study. Arthritis Res Ther 2005; 7:R666-76.

58. Ko JM, Gottlieb AB, Kerbleski JF. Induction and exacerbation of psoriasis with TNF-blockade therapy: a review and analysis of 127 cases. J Dermatolog Treat 2009;20:100-8.

59. Harrison MJ, Dixon WG, Watson KD, King Y, Groves R, Hyrich KL, et al. Rates of new-onset psoriasis in patients with rheumatoid arthritis receiving anti-tumour necrosis factor alpha therapy: results from the British Society for Rheumatology Biologics Register. Ann Rheum Dis 2009;68:209-15.

60. Wetter DA, Davis MD. Lupus-like syndrome attributable to anti-tumor necrosis factor alpha therapy in 14 patients during an 8-year period at Mayo Clinic. Mayo Clin Proc 2009;84:979-84.

61. Costa MF, Said NR, Zimmermann B. Drug-induced lupus due to anti-tumor necrosis factor alpha agents. Semin Arthritis Rheum 2008;37:381-7.

62. Katz U, Zandman-Goddard G. Drug-induced lupus: an update. Autoimmun Rev 2010;10:46-50.

63. Bodur H, Eser F, Konca S, Arikan S. Infliximab-induced lupus-like syndrome in a patient with ankylosing spondylitis. Rheumatol Int 2009;29:451-4.

64. Altindag O, Aydeniz A, Gursoy S, Yagiz E, Koca I. Lupuslike syndrome during anti TNF-alpha therapy: a case report. Romatizma 2008;23:154-6.
65. Lelong J, Duburque C, Fournier C, Colombel JF, Desreumaux P, Tonnel AB, et al. Desensitisation to infliximab in patients with Crohn's disease. Rev Mal Respir 2005;22:239-46.

66. Bavbek S, Aydin O, Ataman S, Cahill K, Castells M. Injection-site reaction to etanercept: role of skin test in the diagnosis of such reaction and successful desensitization. Allergy 2011;66:1256-7.

67. Abadoglu O, Epozturk K, Atayik E, Kaptanoglu E. Successful rapid rituximab desensitization for hypersensitivity reactions to monoclonal antibodies in a patient with rheumatoid arthritis: a remarkable option. J Investig Allergol Clin Immunol 2011;21:319-21.

68. Mohan N, Edwards ET, Cupps TR, Oliverio PJ, Sandberg $\mathrm{G}$, Crayton $\mathrm{H}$, et al. Demyelination occurring during antitumor necrosis factor alpha therapy for inflammatory arthritides. Arthritis Rheum 2001;44:2862-9.

69. Cruz Fernández-Espartero $M$, Pérez-Zafrilla B, Naranjo A, Esteban C, Ortiz AM, Gómez-Reino JJ, et al. Demyelinating disease in patients treated with TNF antagonists in rheumatology: data from BIOBADASER, a pharmacovigilance database, and a systematic review. Semin Arthritis Rheum 2011;41:524-33.

70. Cay HF, Gungor HA, Sezer I, Kacar C, Balci N. Adverse effect of TNF-alpha blocker? Demyelination in an ankylosing spondylitis patient: a case report. J Clin Pharm Ther 2006;31:645-8.

71. Schiff M, Keiserman M, Codding C, Songcharoen S, Berman A, Nayiager S, et al. Efficacy and safety of abatacept or infliximab vs placebo in ATTEST: a phase III, multi-centre, randomised, double-blind, placebocontrolled study in patients with rheumatoid arthritis and an inadequate response to methotrexate. Ann Rheum Dis 2008;67:1096-103.

72. Lunt M, Watson KD, Dixon WG; British Society for Rheumatology Biologics Register Control Centre Consortium, Symmons DP, Hyrich KL; British Society for Rheumatology Biologics Register. No evidence of association between anti-tumor necrosis factor treatment and mortality in patients with rheumatoid arthritis: results from the British Society for Rheumatology Biologics Register. Arthritis Rheum 2010;62:3145-53.

73. Altindag O, Aydeniz A, Gursoy S. A Case with Anti TNF- a Induced Bullous Pemhigoid. Turk J Rheumatol 2010;25:214-6.

74. Deniz D, Ebru U, Ajda B, Gulsum TM, Semih T, Aytul C. A case of cellulitis causing tissue defect during etanercept therapy. Rheumatol Int 2012;32:241-4.

75. Dagci H, Zeyrek F, Gerzile YK, Sahin SB, Yagci S, Uner A. A case of myiasis in a patient with psoriasis from Turkey. Parasitol Int 2008;57:239-41.

76. Sendur OF, Turan Y, Berkit IK, Tastaban E. Angiooedema in a patient treated with etanercept for rheumatoid arthritis. Basic Clin Pharmacol Toxicol 2009;104:488-90. 
77. Sari I, Akar S, Birlik M, Sis B, Onen F, Akkoc N. Anti-tumor necrosis factor-alpha-induced psoriasis. J Rheumatol 2006;33:1411-4.

78. Tutar E, Ekici F, Naçar N, Arici S, Atalay S. Delayed maculopapular, urticarial rash due to infliximab in two children with systemic onset juvenile idiopathic arthritis. Rheumatology (Oxford) 2004;43:674-5.

79. Yazisiz V, Avci AB, Erbasan F, Yildirim B, Terzioğlu E. Development of Crohn's disease following anti-tumour necrosis factor therapy (etanercept). Colorectal Dis 2008;10:953-4.

80. Ekici B, Aydın K, Cantez S, Ergül Y, Tatlı B. Etanerceptinduced encephalopathy in a 7-year-old child. Pediatr Neurol 2011;45:271-3.

81. Bodur H, Eser F, Konca S, Arikan S. Infliximab-induced lupus-like syndrome in a patient with ankylosing spondylitis. Rheumatol Int 2009;29:451-4.

82. Capkin E, Karkucak M, Yayli S, Aydin Çapkin A, Tosun M. Infliximab-induced palmoplantar psoriasis in a patient with ankylosing spondylitis. J Clin Rheumatol 2011;17:293-4.

83. Bal A, Gurcay E, Aydog E, Umay E, Tatlican S, Cakci A. Onset of psoriasis induced by infliximab. J Clin Rheumatol 2008;14:128-9.

84. Sarpel T, Basaran S, Akcam FD, Günasti S, Denli Y. Psoriasis induced by tumor necrosis factor-alpha antagonist therapy: Case series and literature overview. Turk J Rheumatol 2010;25:91-4.

85. Nalbant S, Özyurt M, Yıldırım M, Kuskucu M. Pulmonary tuberculosis and tuberculous arthritis of knee joint associated with rheumatoid arthritis treated with antitumor necrosis factor (TNF)-alpha medication: a case report. Rheumatol Int 2012;32:2863-6.

86. Bes C, Soy M. Serious menstrual bleeding associated with use of TNF alpha blocker: two cases. Rheumatol Int 2012;32:2175-6.
87. Akoğlu S, Babayiğit C, Karazincir S, Balci A, Hanta I. Tuberculous pleurisy after tumour necrosis factor-alpha antagonist usage: case report. [Article in Turkish] Tuberk Toraks 2008;56:448-52.

88. Akgul O, Calis M, Ozgocmen S. New-onset palmoplantar psoriasis during treatment of active ankylosing spondylitis with TNF-alpha blocking agent adalimumab. Turk J Rheumatol 2011;26:269-70.

89. Marakli SS, Uzun S, Ozbek S, Tuncer I. Dermatitis herpetiformis in a patient receiving infliximab for ankylosing spondylitis. Eur J Dermatol 2008;18:88-9.

90. Sari I, Binicier O, Birlik M, Akar S, Yilmaz E, Kargi A, et al. Thymic enlargement in a patient with juvenile idiopathic arthritis during etanercept therapy. Rheumatol Int 2009;29:591-3.

91. Ozgunes N, Zengin-Elbir T, Yazici S. Pulmonary tuberculosis following the use of infliximab: A case report. Klimik J 2010;23:70-2.

92. Elbek O, Uyar M, Aydin N, Börekçi S, Bayram N, Bayram $\mathrm{H}$, et al. Increased risk of tuberculosis in patients treated with antitumor necrosis factor alpha. Clin Rheumatol 2009;28:421-6.

93. Korkmaz C, Kaşifoglu T, Yaşar B. Acceleration of leftventricular diastolic dysfunction and pulmonary hypertension after TNF-alpha blocker. Ann Pharmacother 2005;39:1138-9.

94. Simsek I, Erdem H, Pay S, Sobaci G, Dinc A. Optic neuritis occurring with anti-tumour necrosis factor alpha therapy. Ann Rheum Dis 2007;66:1255-8.

95. Hanta I, Ozbek S, Kuleci S, Kocabas A. The evaluation of latent tuberculosis in rheumatologic diseases for anti-TNF therapy: experience with 192 patients. Clin Rheumatol 2008;27:1083-6.

96. Cagatay T, Aydin M, Sunmez S, Cagatay P, Gulbaran Z, Gul A, et al. Follow-up results of 702 patients receiving tumor necrosis factor- $\alpha$ antagonists and evaluation of risk of tuberculosis. Rheumatol Int 2010;30:1459-63. 